\title{
THE MESOPOTAMIANS HUNGERED FOR WHAT? LITERATURE, MATERIAL CULTURE, AND OTHER HISTORIES
}

Kátia Maria Paim Pozzer ${ }^{1}$

\begin{abstract}
The analyzes of the symbolic meaning of food, the culinary habits and the behavior at the table were stimulated by the New Cultural History and favored the studies on the relations between food, culture and social structure. Thus, in this article we intend to discuss the Mesopotamian banquet, its sacred roots, the myths of food creation, the material culture and the rich iconography on the subject.
\end{abstract}

\section{Keywords}

Mesopotamia; food; material culture; literature.

\section{Resumo}

As análises sobre a significação simbólica dos alimentos, os hábitos culinários e o comportamento à mesa foram impulsionadas pela Nova História Cultural e favoreceram os estudos sobre as relações entre alimentação, cultura e estrutura social. Assim, neste artigo pretendemos discutir o banquete mesopotâmico, suas raízes sagradas, os mitos de criação dos alimentos, a cultura material e a rica iconografia existente sobre o tema.

\section{Palavras-chave}

Mesopotâmia; alimentação; cultura material; literatura.

\footnotetext{
${ }^{1}$ Assistant Professor, Federal University of Rio Grande do Sul, Porto Alegre, Brazil. Email: katia.pozzer@ufrgs.br
} 
Participate in an academic homage to Prof. Pedro Paulo de Abreu Funari is a privilege because it means that at some point in my professional life I met Pedro Paulo (as he is affectionately called) and I was able to share his wisdom and generosity. Undoubtedly, Prof. Funari is one of the Brazilian exponents of History and Archeology, with greater insertion and international recognition. He has become an example of a serious and prolific academic course in the country. Thus, my research on the history of food, based on the interlocution between material culture, especially its visuality, and the literary texts are inspired by the works of our honoree.

The analysis of the symbolic significance of food, culinary habits and table behavior was driven by the New Cultural History and favored studies on the relationships between food, culture and social structure (Flandrin and Montanari, 1998). Thus, in this article we intend to discuss the Mesopotamian banquet, its sacred roots, the myths of food creation, the material culture and the rich iconography on the subject.

The origin of agriculture and livestock in Mesopotamia is a subject of mythological literature. The following text, partially transcribed, entitled Ašnan v. Lahar, reports the emergence of cereals and small animals on land (Bottéro, 1993: 511-513)2:

When, upon the mountains of the universe,

$\mathrm{An}^{3}$ placed the Anunna ${ }^{4}$ in the world,

He did not put, at the same moment, in the world

Nor did he appear Cereal (Ašnan),

Nor has it produced in the country the Uttu ${ }^{5}$

Nor did he prepare the weaver profession for them.

The Mother Sheep (Lahar) did not yet exist,

The rams did not multiply;

The Goat-mother did not exist either,

The kids did not multiply (...)

Because the Anunna, the great gods, ignored

Cereal, the generous, and Mother sheep,

There was neither grain, nor šegusu ${ }^{6}(. .$.$) ,$

There were no clothes to wear (...).

Also the men of these times indented

They did not even know how to eat bread,

Not even cover yourself with the clothes:

They came and went naked,

If they feed on grass, as the sheep do,

\footnotetext{
2 All translations of texts in modern languages are the author's.

${ }^{3}$ An: Mesopotamian divinity leader of the gods is also the Sumerian name for heaven.

4 Primitive deities, those that were created first and are not differentiated from each other.

5 Sumerian goddess associated with weaving.

${ }^{6}$ Species of bitter barley.
} 
And drinking only water from the springs in the mountains.

It is then, that in their place of birth, in the sacred mountains,

The gods created Mother Sheep and Cereal, the generous,

That they introduced them together in their meals! (...)

The Anunna of the sacred mountains consumed these products

From the Mother Sheep and Cereal,

Without, however, they are satisfied.

The Anunna of the sacred mountains

They drank the delicious milk from their stable,

However, do not be satisfied:

That is why they gave men the breath of life.

Enki ${ }^{7}$ then tells Enlilis:

Oh venerable Enlil, bring down upon the earth Mother sheep and Cereal!

Thus, on the orders of Enki and Enlil,

Mother sheep and Cereal descended down here from the sacred mountains.

In this text, the two food-protective deities, of plant and animal origin domesticated by man since the Neolithic period, argue as archetypes of two different realities and visuality they compare. We find in this document the mythological explanation for the origin of cereals used in food and clothing (linen) and small animals, whose domestication dates from VII millennium BCE, and which were part of the diet of most of the population of the time. In addition, implicit in the last six lines of the document, is the cause of the emergence of man on earth, which is to serve the gods

According to Mesopotamian mythology, the creation of man by the gods responds to a precise motive: humans must work to support the gods and free them from any material need. Within the Mesopotamian imaginary, the gods enjoyed the same foods as the men: products of agriculture and livestock. These provisions were offered daily in the temples, in the form of blood sacrifices or oblations of vegetable products and beverages. Hence, religious worship is made up of abundant food offerings to the deities, who enjoyed a leisurely and pleasant life, where the banquet had an important place (Sigrist, 1984).

The Mesopotamian epic of creation, known as Enuma Eliš, deals with fundamental ontological issues such as the emergence of the universe, the gods and man. In this text, we also find references to the banquet. The poem, with seven songs and a total of 1,100 verses, would have been written during the reign of Nebuchadnezzar I (1124 - 1103 BCE). It is believed to be a required study text in the scribal and priests' preparatory schools, being recited during New Year's Eve celebrations.

\footnotetext{
7 Enki, sumerian name of its equivalent in akkadien, Ea, the God responsible for the creation of the Man, according to Mesopotamian mythology.

8 The most important god of the Mesopotamian pantheon, Enlil is the king of the gods.
} 
In the first tablet is told the origin of the universe, when the sky and the earth had not yet been named, so they did not yet exist. There was only a primordial aquatic chaos, containing a male element, Apsu, fresh water, and a female element, Tiamat, salt water.

The second song relates a dispute between Tiamat and the other deities and the convening of a meeting of the gods to resolve the conflict.

It is in the third tablet that this meeting is narrated in a very succinct way (Peinado, 1994: 59-63):

(...) may all the gods come here,

who hold talks,

that take place at the banquet;

let them eat their bread,

drink your beer,

and fix their fate (...)

All the Great Gods who fix the destinies,

came in the presence of Ašar and were filled with joy,

kissed each other in their Assembly

and they sat down and sat down to the banquet.

They ate their festive bread and drank their beer,

their cups were filled with sweet liquor.

Sipping the exciting drink, they felt their bodies

and without the slightest concern, exalted his heart,

and to Marduk, his avenger, thus set fate.

In the course of this banquet, the gods decide to choose one among them to fight against the goddess Tiamat and confer to the chosen Marduk ${ }^{9}$ god, full powers.

We see, through mythology, the role of the solemn and collective banquet, it is not simply the stage of a meal, of the pleasure of gastronomy, but it is the occasion for diners to make important decisions for their own interests. That is, the banquet acquires, besides the social meeting, the function of a political character. (Glassner, 2003: 45).

\section{Food and Material Culture}

The archaeological excavations of the ancient Near East made it possible to identify a rich diversity of Mesopotamian products: cereals, various vegetables, fruits - such as dates, apples, pears, figs, pomegranates, grapes and roots, truffles and mushrooms, condiment herbs. They consumed small and medium-sized animals: pigs, poultry (except

${ }^{9}$ Marduk was the protector-god of the city of Babylon. 
chickens, late arrivals), from which eggs were ingested, and hunting animals, freshwater and saltwater fish, crustaceans, shellfish and insects such as grasshoppers (Figs 1 and 2); milk, butter and other vegetable fats, especially sesame and olive, honey and mineral products such as salt and ash. (Stol, 2000: 496-497).

The consumption of beef was carried out, preferably, during festive activities, both in the temples as in the palaces. The meat of hunting animals such as wild boar, gazelles and wild birds was also consumed. As we can see in this detail of Assyrian bas-relief (Fig. 3). Archaeological excavations carried out in residential areas within cities found a diversity of bird bones, testifying to their widespread consumption among the Mesopotamians (Joannès, 2001: 911).

We have evidence that the Mesopotamians created multiple ways of transforming food by developing various conservation techniques, especially sun-dried foods: cereals, vegetables and fruits (dates, grapes and figs), meat and fish, which have probably learned to smoke ; preserves in salt or olive oil: fish and various meats (Fig. 4); and preserves in honey: fruits.

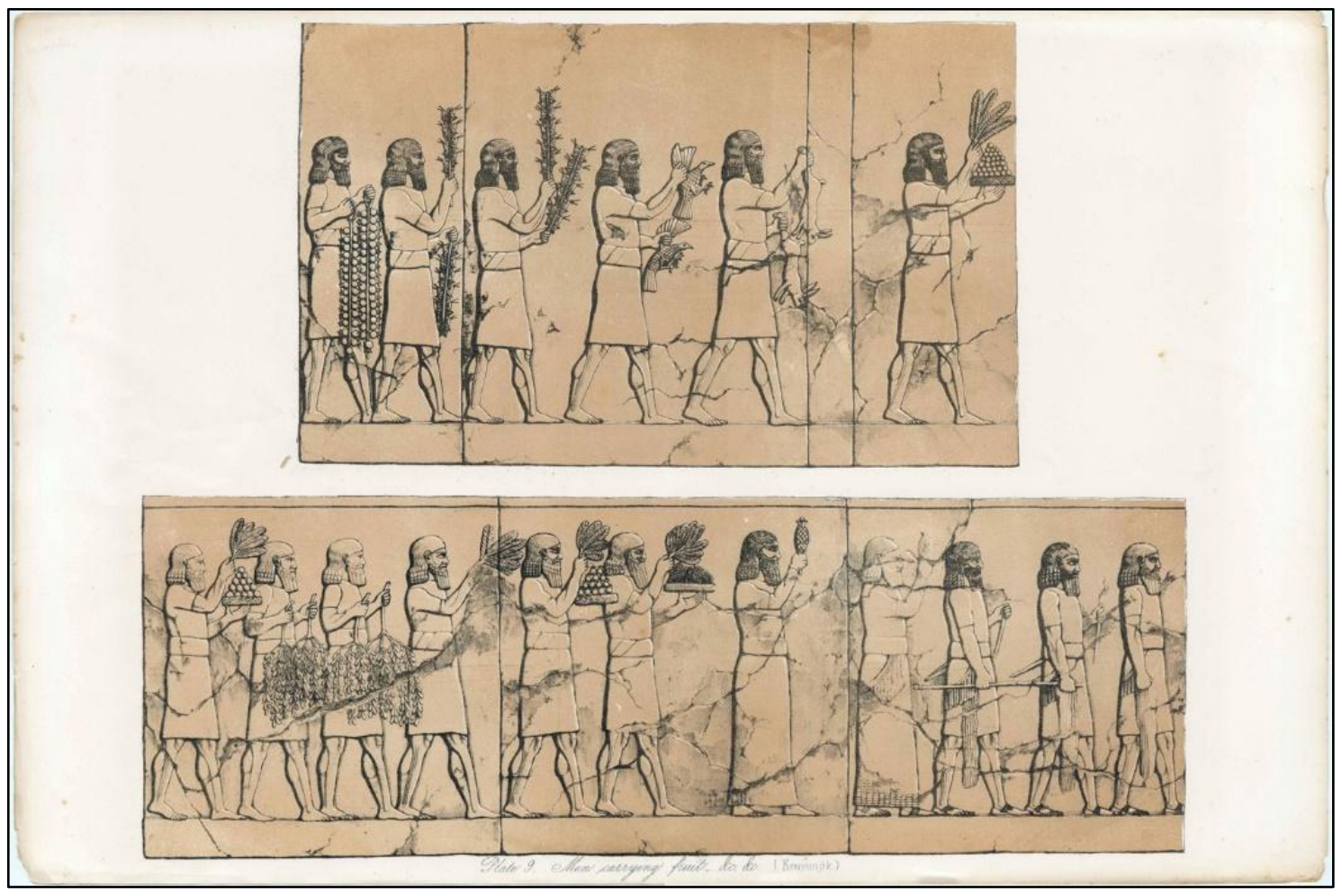

Fig. 1. Banquet preparation scene. Source: Layard, 1853, vol 1: 24. 


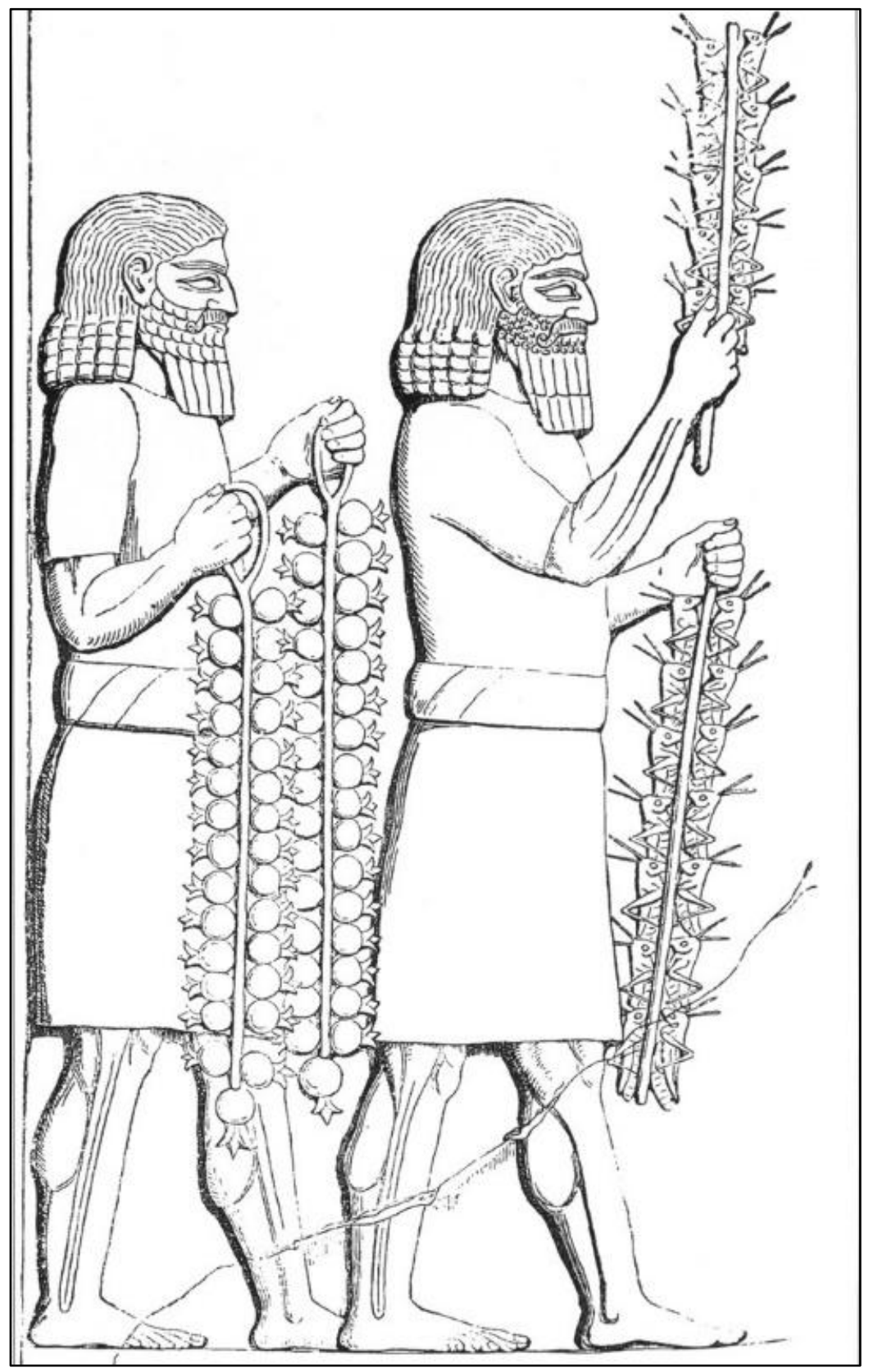

Fig. 2. Banquet preparation scene (detail). Source: Layard, 1853, vol 1: 24.

They also produced a brine used as a condiment and preserved, based on fish, crustaceans or locusts, called šiqqu, comparable to the Roman garum and the Japanese oyster sauce of the present day. It is known that they used the milk fermentation to produce fresh cheeses and a kind of yogurt. We can identify the butter preparation in this relief from Tell el-Ubaid (Fig. 5). 


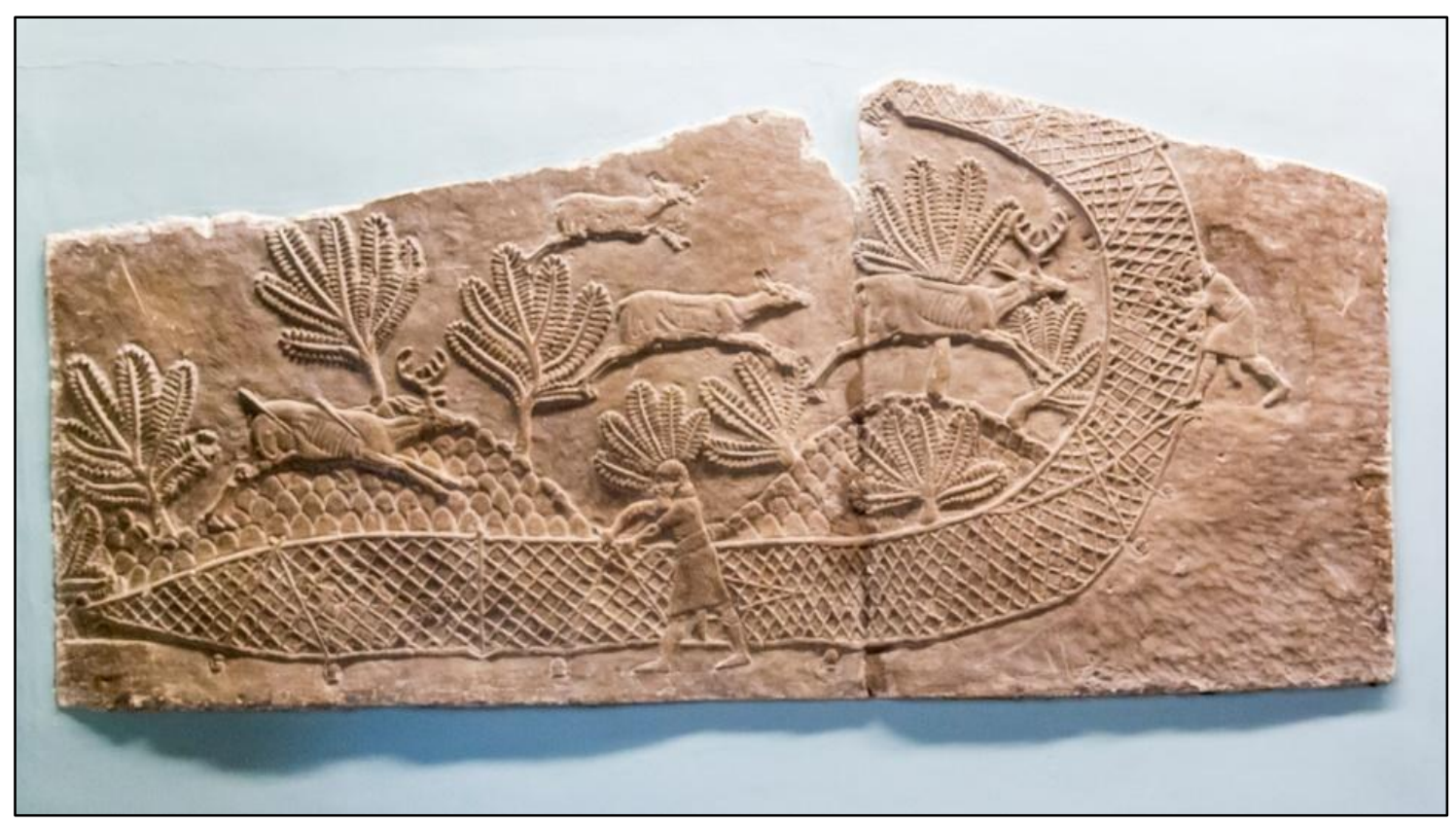

Fig. 3. Hunting scene with deer, bas-relief in alabaster. Source: Assyria, 645-635 BCE. Nineveh, North Palace, Room S. British Museum. Author's photo.

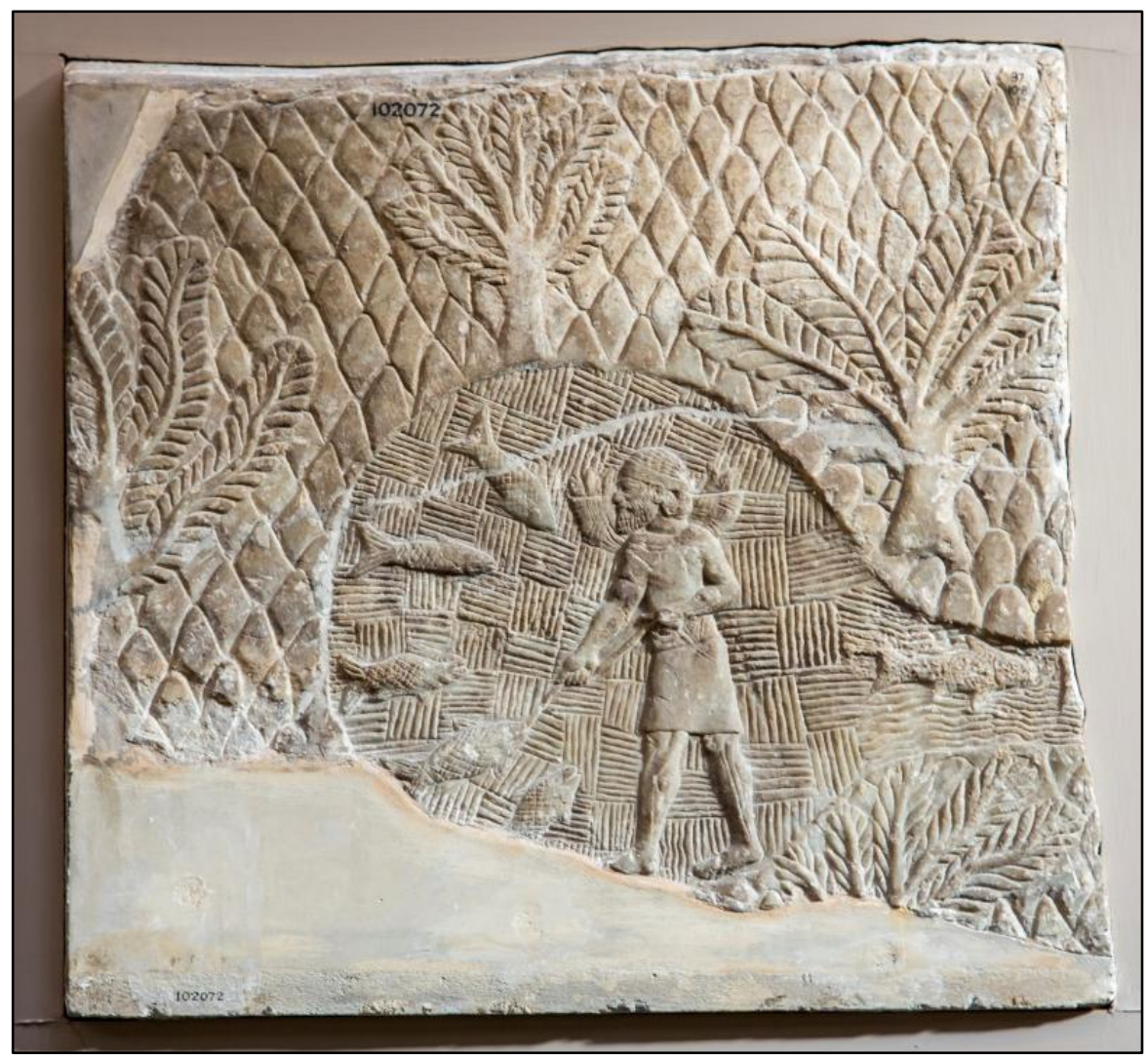

Fig. 4. Fishing scene in a lake with hook, bas-relief in alabaster. Source: Assyria, 700692 BCE. Nineveh, Southwest Palace, room XLV. British Museum. Author's photo. 


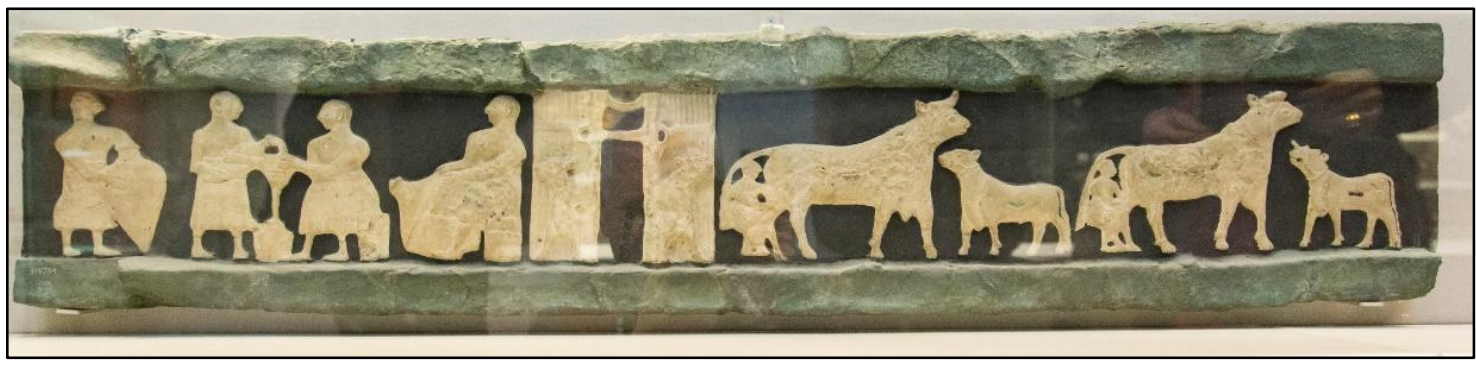

Fig. 5. Scene of preparation of butter, ivory mosaic. Source: Ninhursag Temple, Tell elUbaid, 2500 BCE. British Museum. Author's photo.

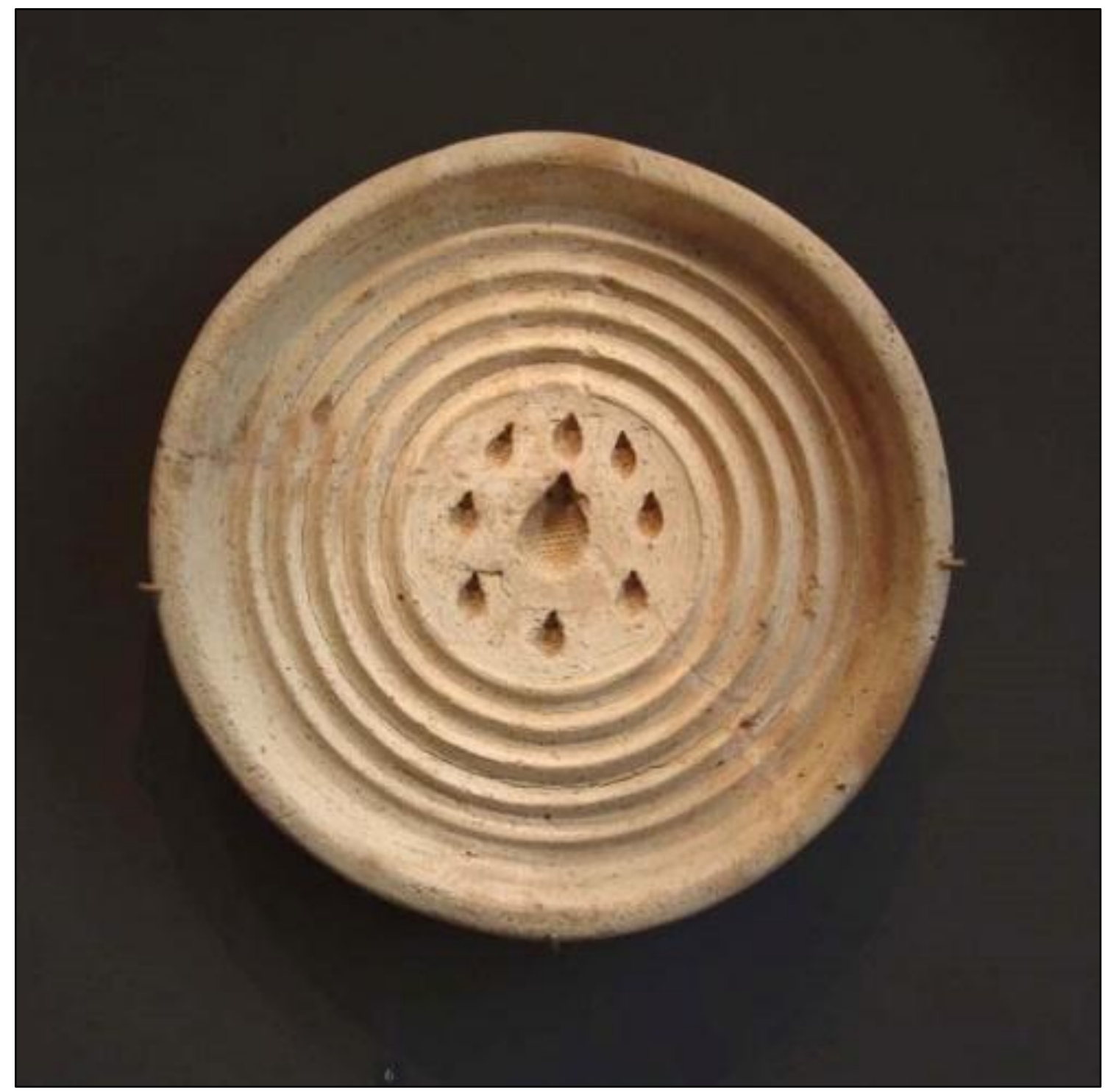

Fig. 6. Bread loaf in clay. Palace of Mari, room 77. Beginning of the II millennium BCE. Source: Louvre Museum. Author's photo.

The cereals were milled and sifted to make meal and flour of different grain sizes. From these flours were produced boiled and pasta, which

Heródoto, Unifesp, Guarulhos, v. 2, n. 2, Dezembro, 2017. p. 153-167 - 160 - 
could be fermented or not. Food could be grilled or baked directly in the flames or cooked more slowly under coals and ashes. The ovens were also used and the cooking was in liquid medium - animal greases and especially water -, where two main types of pots were used: the ceramic pot (diqâru) and the bronze cauldron (ruqqu).

Among the rich documentation on the tangible world produced by the Mesopotamian scribes is the Sumerian Lexicon Material (MSL), a bilingual catalog, in two-column, Sumerian and Acadian, of all material components of the Mesopotamian world, classified into several categories. The texts are organized in 24 tablets, with 400 themed items each, the last two of which were reserved for the "Food" sector. From this list we can extract 18 or 20 qualities of cheeses, a hundred types of soups (Sumerian TU, Akkadian ummaru), about 300 qualities of breads (ranging from flour, yeast, olive oil, milk or beer, sweet or seasoned with fruits, etc.), where the shape also varied (small or large, thick or thin, in the form of heart, head, hand, ear, animals or deities) (Figures 6, 7 and 8). The aesthetic question of food was so important that the Akkadian title for the chef, the equivalent of the current chef de cuisine, was mubann $\hat{u}$, whose literal translation is "the beautifier."

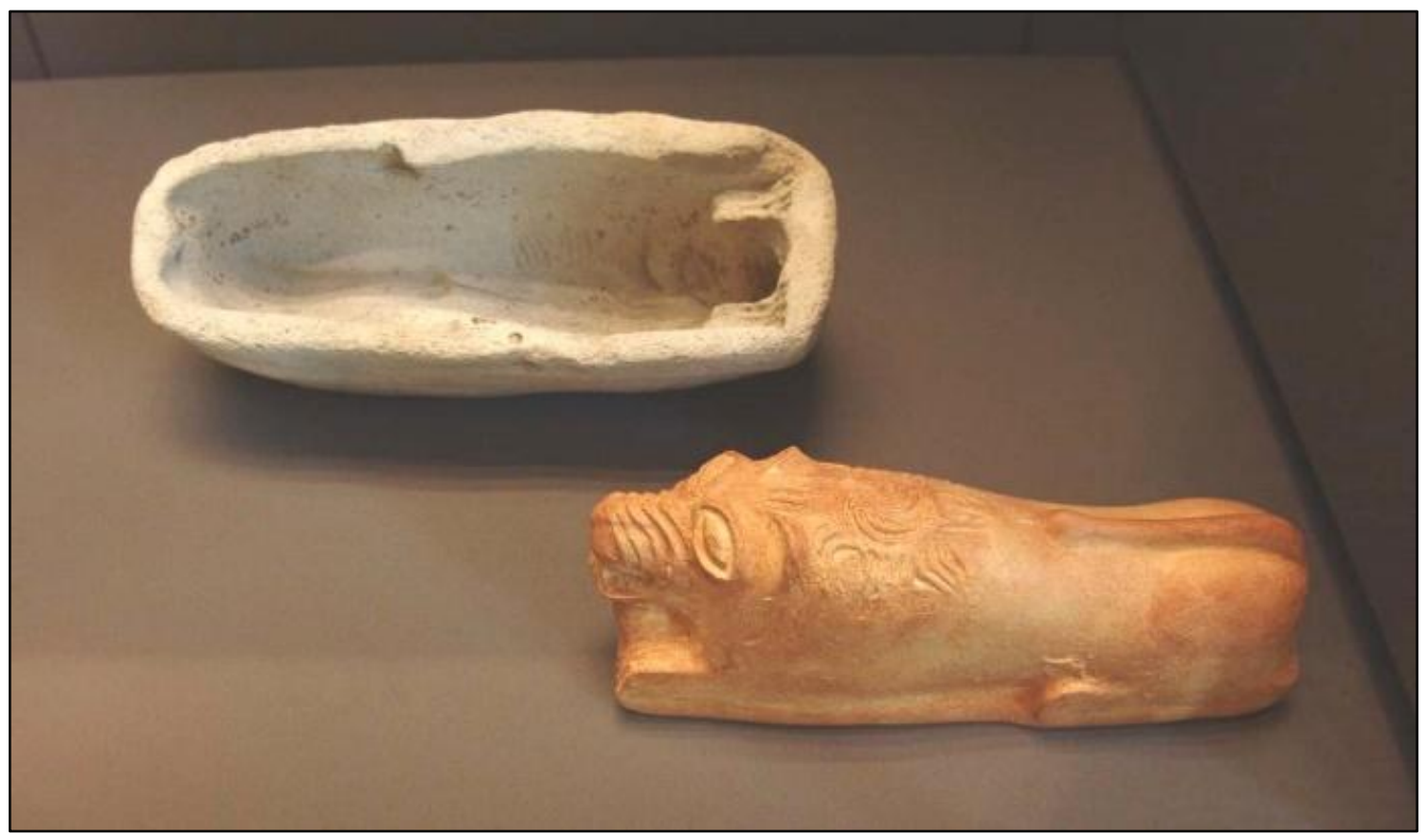

Fig. 7. Bread loaf in clay and modern replica. Palace of Mari, room 77. Beginning of the II millennium BCE. Source: Louvre Museum. Author's photo. 


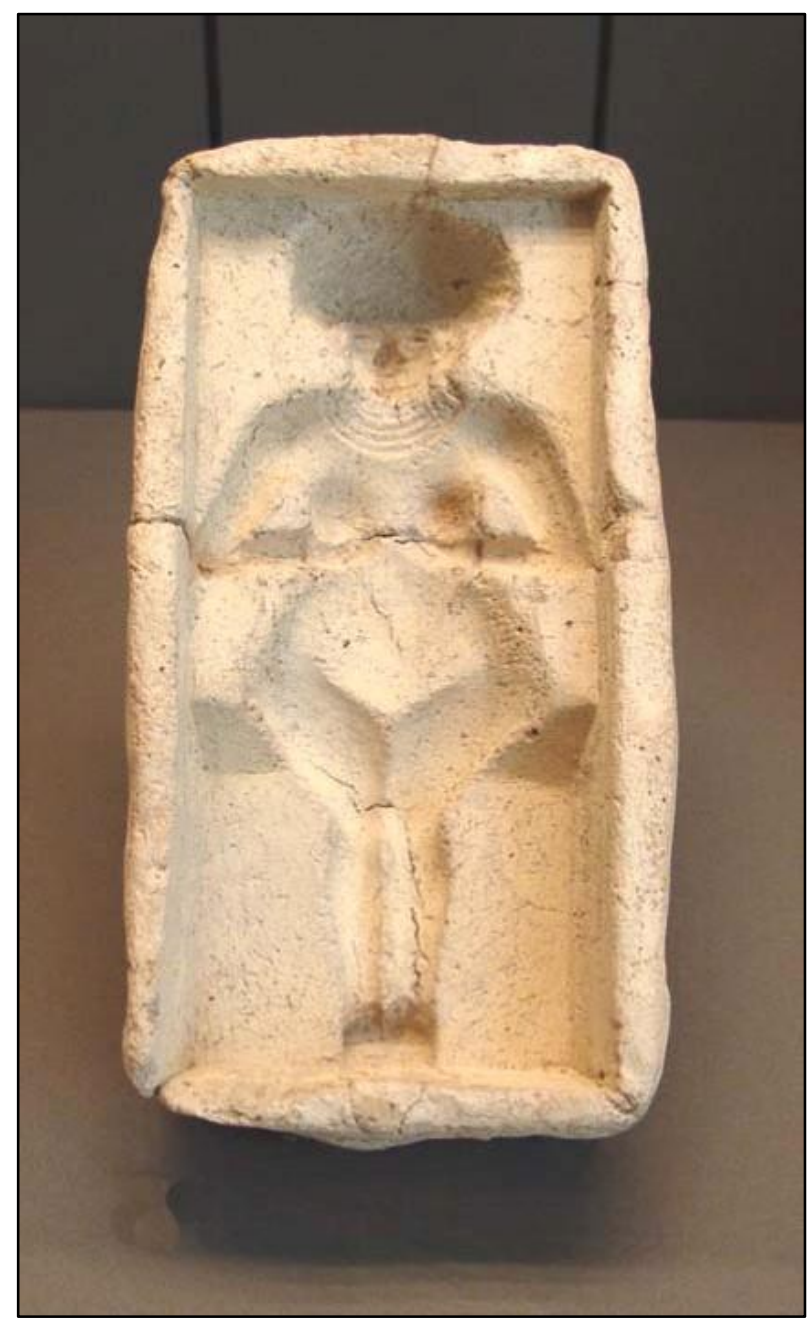

Fig. 8. Bread loaf in clay. Palace of Mari, room 77. Beginning of the II millennium BCE. Source: Louvre Museum. Author's photo.

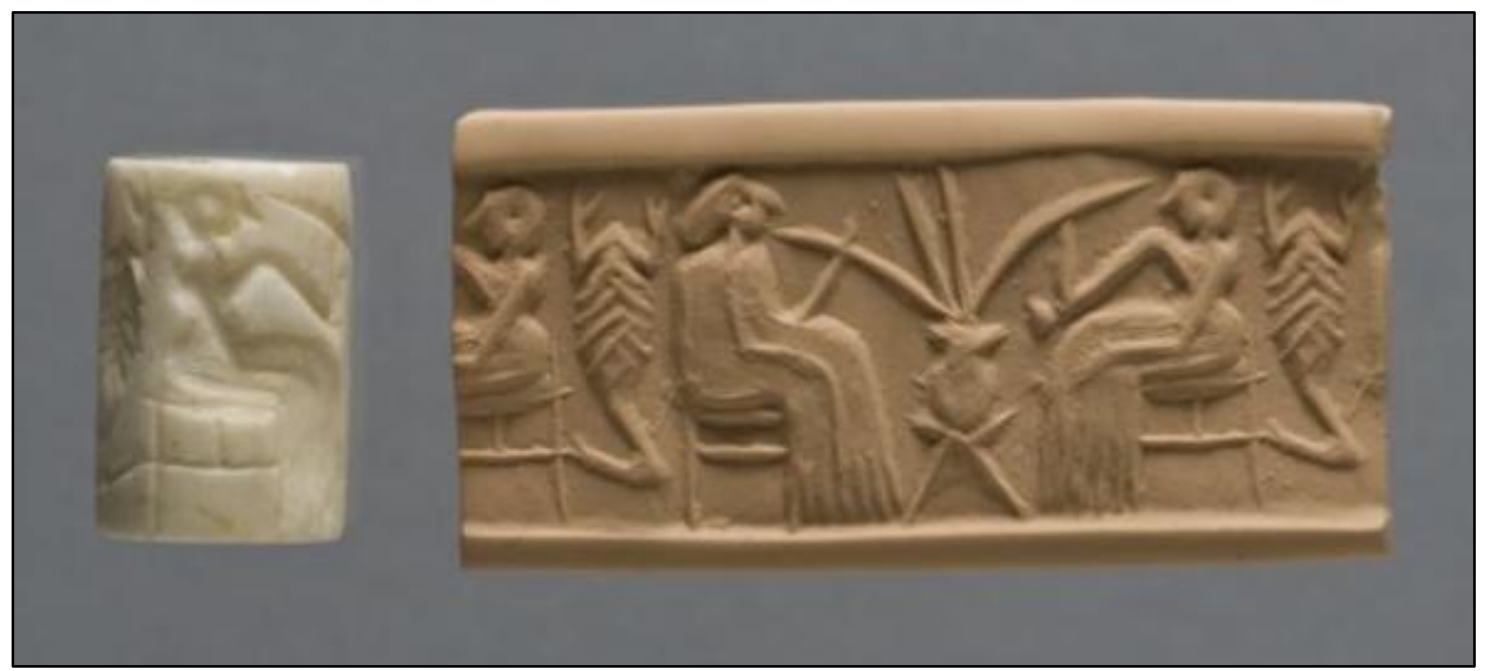

Fig 9. Cylinder-Seal. Ancient Dynastic Period (2600-2350 BCE). Khafajeh, Iraq. Source: Eastern Institute of Chicago. 
The earliest known culinary recipe, dating from the beginning of the 2nd millennium BCE, could be called Honey Bread and Spices, mersu, in Acadian and ninda.dé.a in Sumerian, and had ingredients such as flour, water, milk or beer, olive oil or butter to humidify, as well as dates and dried fruits such as grapes, figs or apples and a kind of pinion. It was seasoned with four aromatic condiments: nigella, cumin, coriander and garlic, and sweetened with honey. The final appearance of the dish was of bread baked in the oven. (Bottéro, 1995).

Besides eating, the Mesopotamians also drank. Beer, considered the most popular and oldest drink in the region, as it predates the third millennium BCE, was a key ingredient in any banquet in Mesopotamia. According to improved techniques, this fermented cereal drink was prepared in more than 30 different ways: white, red, light, dark, sweetened with honey and perfumed with multiple aromas. In general, it was drank collectively, sucking, in the same jar, with straws with a sort of filter in the end, in order to eliminate the impurities of the same.

In ancient Mesopotamia, beer was considered a gift from the gods, a demarcate of civilization, a staple food and a ritual necessity. It was produced on a large scale and consumed daily by people from the most diverse socioeconomic strata. In fact, beer was "liquid bread", a fundamental source of sustenance. However, what gave the beer its power and distinctive appeal were its intoxicating effects.

Known as kaš in Sumerian or šikaru in Acadian, it was a fermented barley-based drink, typically made from two key ingredients: malted barley and a special type of barley bread called bappir. The best description of the manufacturing process itself can be found in a literary document, the famous Hymn to Ninkasi, goddess of beer:

Given the birth by flowing water [...], tenderly cared for by Ninhursaja! Ninkasi, birthed by the flowing water [...], tenderly cared for by Ninhursaja!

It is you who handle the [...] and dough with a big shovel, mixing, in a pit, the beerbread with sweet aromatics. Ninkasi, it is you who handle the [...] and dough with a big shovel, mixing, in a pit, the beerbread with sweet aromatics. $[\ldots]$

You [...] the sweetwort to the vessel. Ninkasi, [...] You [...] the sweetwort to the vessel.

You place the fermenting vat, which makes a pleasant sound, appropriately on top of a large collector vat. Ninkasi, you place the fermenting vat, which makes a pleasant sound, appropriately on top of a large collector vat. 
It is you who pour out the filtered beer of the collector vat; it is like the onrush of the Tigris and the Euphrates. Ninkasi, it is you who pour out the filtered beer of the collector vat; it is like the onrush of the Tigris and the Euphrates. ${ }^{10}$

According to one of the most important literary texts of the Mesopotamian civilization, dating from the first millennium BCE, and known as the Epic of Gilgameš, drinking beer was part of the civilizing process of Enkidu. He is a wild creature that lived among animals: first, he had sex with a woman, a courtesan, for six days and seven nights; then he ate bread and drank beer, then washed and perfumed himself and changed into clean clothes. That is how he became a civilized man! (Pozzer, 2014). We reproduce some lines of the text, from the second tablet, first column (Bottéro, 1992c: 224):

Enkidu did not know bread as food; he ignored beer as a drink. The courtesan, opening her mouth, tells Enkidu: "Eat bread, Enkidu, it is the sign of civilized life, drink beer, it is the custom in the civilized country." Enkidu ate his bread until he was satisfied, drank the beer seven times, his heart relaxed and he began to sing happily.

They also knew the wine, coming from the north and northeast of Mesopotamia. Wine was a rare drink, considered luxurious by the Mesopotamians, where only the gods and kings would have the privilege of consuming it. The word GEŠTIN, in Sumerian, designated at the same time the vine and the wine. The vineyard would have been planted in Sumerian for grape consumption. Wine was imported from the mountainous regions of Syria and Armenia (Lion, Michel, 2001: 139).

\section{The Kalhu Stela - An Outstanding Document}

The inauguration of royal palaces was a privileged occasion for large banquets. Moreover, among the most well documented are the sumptuous banquet offered by Assurnazirpal II (883-859 BCE), Assyrian king, when he inaugurated the new capital of his kingdom, the city of Kalhu. The city, known by the biblical name of Kalah, is now in Iraq at the archaeological site of Nimrud, about $25 \mathrm{~km}$ south of Mosul. This account is recorded in a stone stele, found locally in 1951 (Joannès, 1998: 62). It is a unique text, which lists military campaigns, imports of trees to adorn the royal gardens, and the evocation of the banquet (Pritchard, 1975: 99):

When Assurnazirpal, king of Assyria, inaugurated the palace of joy, the palace filled with wisdom, of the city of Kalhu, he invited the god Aššur, the great Lord and the gods of the whole country.

10 http:/ / etcsl.orinst.ox.ac.uk/section4/c4231.htm 
100 fat ox, 1,000 calves and sheeps, 14,000 bought sheeps from Ištar, my Lady, (...) 1,000 big ducks, 500 geese, 10,000 doves, 10,000 fishes, 10,000 eggs. 10,000 breads, 10,000 jugs of beer, 10,000 more of wine, 10,000 containers of chickpeas and sesame, (...), 1,000 boxes of vegetables, 300 containers of oil, 300 containers of fine herbs. 100 containers of pomegranate, 100 containers of grape, 100 containers of fruits, 100 containers of garnic, 100 containers of onion, 100 containers of honey, 100 containers of milk, 100 containers of cheese, (...).

When I inaugurated the palace of the city of Kalhu, 47,074 men and women who were invited from all districts of my country, 5,000 dignitaries and envoys of people from countries of Suhu, Tire, Sidon, (...), a total of 69,574 people, for 10 days I fed them, I gave them to drink, I offered them bath and oils (perfumed). So I honored them and sent them back to their country in peace and happiness.

The figures presented in this report may be fictitious, but they attest to the grandiosity of this inauguration and the cunning of the Assyrian king to demonstrate their power and ensure the preservation of the memory of this important historical event, as well as revealing an aspect of sociability practices of the time.

\section{Conclusion}

Mosaic iconography, archaeological objects, and epigraphic documentation reveal the social importance of pleasure at the table in the Mesopotamian world. In the Babylonian imagery, eating and drinking together served to strengthen friendship among equals and to strengthen relations between the king and his subjects. The sharing of food, more than the composition of the meal itself, was the most important. What founded the banquet was this commensality among the participants and referred to one of the expressions of the basic solidarity of the community.

It is important to note that literary texts also provided information on food preparation techniques and court food preferences.

The feast was also a political act, ritualized and sacred. At the banquet were peace agreements sealed between men and guaranteed divine protection to make life on earth more prosperous and happier.

In Mesopotamia, the great decisions on questions of the universe, of nature and of culture, were taken by the gods at the table in the midst of a great banquet. 


\section{Bibliographic References}

BLACK, J., GEORGE, A.; POSTGATE, N. A Concise Dictionary of Akkadian. Wiesbaden: Harrassowitz Verlag, 2000.

BLACK, J.; GREEN, A. Gods, demons and symbols of Ancient Mesopotamia. London: British Museum Press, 1998.

BORGER, R. Assyrisch-babylonische Zeichenliste. Neukirchen-Vluyn: Verlag Butzon \& Bercker Kevelaer, 1978.

BOTTÉRO, J. La plus vieille cuisine du monde. In: BOTTÉRO, J. Iniciation à l'Orient ancien. Paris: Éditions du Seuil, 1992a. p.81-101.

Le plus vieux festin du monde. In: BOTTÉRO, J. Iniciation à l'Orient ancien. Paris: Éditions du Seuil, 1992b. p.104-121.

- Textes Culinaires Mésopotamiens - Mesopotamian Culinary

Texts. Winona Lake: Eisenbrauns, 1995.

L'Épopée de Gilgameš - Le grand homme qui ne voulait pas mourir. Paris: Gallimard, 1992.

BOTTÉRO, J.; KRAMER, S. Lorsque les dieux faisaient l'homme. Paris: Éditions Gallimard, 1993.

CAD. Chicago Assyrian Dictionary. Chicago: Oriental Institute, 21 vol., 1956-1995.

FLANDRIN, J.-L.; MONTANARI, M. História da Alimentação. Tradução de Luciano V. Machado e Guilherme J. F. Teixeira. São Paulo: Estação Liberdade, 1998.

GLASSNER, J.-J. La Mésopotamie. Paris: Les Belles Lettres, 2002.

. La réception de l'hôte, le vivre et le couvert. Dossiers d'Archéologie, n. 280, 2003. p. 44-47.

HALLO, W. Origins - The Ancient Near Eastern background of some Modern Western institutions. Leiden-New York-Köln: E. J. Brill, 1996.

JOANNÈS, F. A função social do banquete nas primeiras civilizações. In: FLANDRIN, J.-L.; MONTANARI, M. História da Alimentação. Tradução de Luciano V. Machado e Guilherme J. F. Teixeira. São Paulo: Estação Liberdade, 1998, p.54-67.

Laffont, 2001.

Dictionnaire de la Civilisation Mésopotamienne. Paris: Robet

LABAT, R.; MALBRAN-LABAT, F. Manuel d'Épigraphie Akkadienne. Paris: Librairie Orientaliste Paul Geuthner, 1988.

LAYARD, A.H. The Monuments of Niniveh. London: John Murray, 1853.

LION, B.; MICHEL, C. Un banquet à la cour assyrienne. Dossiers d'Archéologie. Dijon: Éditions Faton, n. 280, p. 24-31, 2003.

MALBRAN-LABAT, F. Gilgamesh. Paris: Éditions du Cerf, s.d.

OPPENHEIM, A. Leo. Ancient Mesopotamia - Portrait of a Dead Civilization.

Chicago \& London: The University of Chicago Press, 1977.

PEINADO, F. L. Enuma Elish. Madrid: Editorial Trotta, 1994. 
POZZER, K.M.P. O Banquete do Rei e a Política nos Tempos de Paz. In: Cerqueira, F.V.; Gonçalves, A.T.; Nobre, C.K.; Silva, G.J.; Vargas, A.Z. Guerra e Paz no Mundo Antigo. Pelotas: Leeparq/UFPel, IMP, 2007. p. 139152.

A Epopeia de Gilgameš Amizade e Morte na Mesopotâmia In: SANTOS, D (org.). Grandes Epopeias da Antiguidade e do Medievo. Blumenau: Edifurb, 2014, p. 42-53.

PRITCHARD, J. B. Ancient Near Eastern Texts Relating to the Old Testament. Princeton: Princeton University Press, 1950.

ROAF, M. Atlas de la Mésopotamie. Paris: Brepols, 1991.

SIGRIST, M. Les sattukku dans l'Ešumeša durant la période d'Isin et Larsa. BiMes 11, Malibu, 1984.

STOL, M. Private life in Ancient Mesopotamia. In: SASSON, J. M. (Editor). Civilizations of the Ancient Near East. New York: Scribner, 2000. p.485-501.

ZIEGLER, N. Diplomatie à la table du roi. Dossiers d'Archéologie. Dijon: Édition Faton, n. 280, p. 16-23, 2003. 